\title{
Pre-Treatment with Intravenous Granisetron to Alleviate Pain on Propofol Injection: A Double Blind Randomised Controlled Study Using Normal Saline as Control
}

\author{
Tarun Tyagi ${ }^{1}$ Shashikant Shinde ${ }^{2}$ \\ ${ }^{I}$ Student Department of Anaesthesiology, Critical Care \& Pain, Seth G S Medical College \& KEM Hospital, \\ Mumbai, India \\ ${ }^{2}$ Associate professor Department of Anaesthesiology, Critical Care \& Pain, Seth G S Medical College \& KEM \\ Hospital, Mumbai, India.
}

\begin{abstract}
BACKGROUND: Pain on injection is one of the most commonly reported side effect of Propofol, there are numerous pharmacological and non pharmacological methods to reduce it. This study compares the efficacy of intra-venous Granisetron with normal saline pre-treatment to reduce pain on propofol treatment, measured on verbal rating pain scale.
\end{abstract}

MATERIAL \& METHODS: It was a double blind randomized controlled study. After approval from Institutional ethics committee 82 patients were randomly allocated into 2 groups. 41 patients were given intravenous Granisetron and other 41 were given normal saline pre-treatment before Propofol injection.

RESULTS: Mean age in Granisetron group is $38.43+13.16$ and $42.46+13.49 . p=0.1756$, using unpaired t-test indicating that the age of the patients in the NS group is significantly greater as compared to granisetron group. In the granisetron group 39\% were male patients and 61\% were female patients whereas NS group had $61 \%$ male patients and $39 \%$ female patients; with a $\mathrm{p}$ value of 0.0772 indicating the proportion of females in granisetron group is significantly greater as compared to that in normal saline group. The weight for patients in granisetron group was found to be $61.80 \pm 7.76 \mathrm{~kg}$ and for NS group was $67.16 \pm 10.03 \mathrm{~kg}$; with p value of 0.0978 indicating that the weight of the patients in the NS group is significantly greater as compared to granisetron group. $\mathrm{p}=0.1804$, using chi-square test indicating no significant difference in the proportion of patients belonging to different ASA class in the two groups. Baseline heart rate was comparable in both the group at pre injection and $1 \mathrm{~min}$ post injection time points. However, at $3 \mathrm{~min}$, heart rate was found to be significantly lower in granisetron group $(79.22 \pm 11.64)$ compared to normal saline group $(88.41 \pm 10.33)$. SpO2 at pre injection, $1 \mathrm{~min}$ and $3 \mathrm{~min}$ post injection was observed comparable in both granisetron and normal saline group. There was no statistical significance difference between observations of $\mathrm{SpO} 2$ up to 3 minutes of observation period. $\mathrm{p}<0.0001$ indicating that the change in SBP was significantly higher in the NS group as compared to the granisetron group. $\mathrm{p}=<0.0001$, indicating that the change in DBP was significantly higher in the NS group as compared to the granisteron group. $\mathrm{p}=0.0001$, using Mann-Whitney test indicating that the pain score was significantly higher in the NS group as compared to the granisetron group.

CONCLUSION: In conclusion,

1.) Granisetron pre-treatment decrease the heart rate, systolic and diastolic blood pressure and pain on injection of propofol.

2.) In comparison with normal saline granisetron was better to reduce the pain on propofol injection

3.) The results of this study were comparable with other studies, which also show similar results.

4.) It provides a simple and safe method of reducing the incidence of pain on injection of propofol with the added advantage of avoiding the administration of other drugs that may be undesirable in certain circumstances.

KEY WORDS: Gransetron, Propofol, verbal rating pain scale.

\section{INTRODUCTION:}

Propofol (2, 6-di-isopropylphenol) is a popular intra venous (IV) anaesthetic induction drug associated with smooth induction and rapid recovery. It is the most widely used IV induction agent for a large variety of purposes like induction of general anaesthesia, total intravenous anaesthesia,sedation,anticonvulsant and as an anti- emetic. 
However, pain on injection, is a clinical disadvantage of the drug, which, according to quantitative systematic reviews, has been reported in up to $70 \%$ of patients. Some patients recall the pain on injection as the most uncomfortable experience during surgery .Many interventions have been been developed and studied-sizes, injection sites, infusion rate, temperature, microfiltration, venous occlusion and bacteriostatic saline. A metaanalysis revealed that of all the mechanical methods, the least incidence of pain was reported when ante cubital vein was used for injection. However the ante-cubital vein cannulation is a discomfort to the patient. Flexion of the arm causes cannula compression and decreased flow of IV fluids. The pharmacological methods include pretreatment with lignocaine propofol admixture, pre-treatment with nonsteroidal inflammatory agents, opioids, ketamine,use of lipid free emulsions and the use of different preparations of propofol. A meta-analysis concluded that the use of propofol lignocaine admixture was the best pharmacological method to decrease the incidence of pain on injection. However there is an indication of reporting bias.

We planned this double blind randomised controlled study to determine the efficacy of pre-treatment with intravenous granisetron in mitigating the pain caused by injection of propofol. This was measured using a pain score known as VRS or verbal rating pain scale.

\section{AIMS \& OBJECTIVES}

1. Primary objective: To determine the efficacy of intra-venous granisetron pre-treatment to alleviate pain on propofol injection.

2. Secondary objective: To measure the outcome variable i.e. verbal pain scale and measure the efficacy of granisetron using this scale.

\section{MATERIAL AND METHODS}

- $\quad$ STUDY DESIGN: Prospective randomised active controlled study. Anaesthesia. STUDY SETTING: This study will be conducted in our institute under the department of

- $\quad$ STUDY PERIOD: 1 year

ELIGIBILITY CRITERIA: ASA I-II patients undergoing elective surgical procedure under general anaesthesia.

IV.

STATISTICAL ANALYSIS:

Power calculation indicated that recruitment of 41 people in each group which is calculated using EPI calculator@openepi.com would be significant to demonstrate a reduction of pain score of one at a level of significance of $\mathrm{p}<0.05$ and power of $99.3 \%$. Comparison between the quantitative variables of 3 groups, the ANOVA, the qualitative variables, the chi square test or Fischer's exact test were used. All analyses were done using the SPSS software for windows(16.0 version). The statistically significant level was $\mathrm{P}<0.05$.

SAMPLE SIZE ESTIMATION: Sample size of 82 was calculated using quantitative variable of two groups, ANOVA test and fisher's exact test as 82. The sample was divided into 2 groups of 41 each.

Group A: In this group intra-venous granisetron was administered before Propofol as pre-treatment solution. Group B: In this group intra-venous normal saline was administered before Propofol as pre-treatment solution. RANDOMIZATION PATIENTS: Randomization of the patients will be done by the concealment method. INCLUSION CRITERIAS

- $\quad$ Patients aged between 18 -50 years.

- $\quad$ ASA(American Society of Anaesthesiologists) GRADES I \& II

- $\quad$ All elective surgeries under General Anesthesia.

EXCLUSION CRITERIAS

- $\quad$ Patient's refusal.

- $\quad$ Emergency patients

- Patients with difficulty in communication.

- Patients with a history of allergic response to propofol or 5HT receptor antagonist.

- Patients who had received any analgesic, sedatives or pro-kinetic drugs within 12 hours prior to surgery.

- $\quad$ Pregnant women

\section{METHODOLOGY}

\section{Sample size-82 patients}


Patients undergoing all surgeries, and meeting the inclusion criteria mentioned in the protocol will be recruited in the study.

Type of surgery would not be a confounding factor for our result, all confounding factors will be matched. We are going to keep the following factors same in both the groups:

Type of vein -ante-cubital

Person administering propofol will be the same

Dose of propofol-2 cc

- $\quad$ All patients will be fasting for $8 \mathrm{~h}$.

- $\quad$ Patients will receive either granisetron pre-treatment $2 \mathrm{mg}$ in a total volume of $2 \mathrm{~mL}$ or $2 \mathrm{~mL} 0.9 \%$

saline pre-treatment as a placebo $60 \mathrm{~s}$ before the administration of propofol according to a computer-generated randomization list.

.Placebo in our study is Normal Saline which will serve as the control group. We will compare the efficacy of intravenous granisetron pre-treatment with this placebo group, for reducing pain on propofol injection.

.The parent article of our study has been taken from Indian Journal of Anaesthesia March-April; 56(2): 135-138. PMC ID-PMC 3371487.

.The above study was carried out under the department of anaesthesia by Dr. Ahsan Ahmed et al in Apollo hospital, Kolkata, West Bengal.

.This article mentions the use of normal saline as a control group against which our study group granisetron is being tested for its effectiveness as a pre-treatment for preventing pain on propofol injection which is measured using the verbal rating scale.

All drugs were prepared by an anaesthesiologist not involved in induction of anaesthesia.

- The investigator did not know the content of the solutions.

- No patient was given any pre-medication before the pre-treatment injection.

- In the operation theatre, a 20G cannula was inserted into a vein on the dorsum of the patient's nondominant hand and lactated Ringer's solution was infused.

- Heart rate and non-invasive blood pressure were measured.

- Heart rate, blood pressure and peripheral $\mathrm{O}$ saturation were recorded before injecting propofol and at 1 and 3 min after.

- $\quad$ Each patient received $2 \mathrm{~mL}$ of the pre-treatment solution for a period of $5 \mathrm{~s}$, after i.v. cannulation (time taken for applying monitors) while the venous drainage was occluded manually at mid-arm by an assistant.

- One minute after intravenous injection of pre-treatment solution, the occlusion was released and anaesthesia was induced with propofol $2.5 \mathrm{mg} / \mathrm{kg}$.

- The initial $2 \mathrm{~mL}$ bolus was given over $4 \mathrm{~s}$; 15 seconds later, the patient was asked to rate immediately any sensation of pain during injection of propofol.

- The grading of pain is similar to the method used in previous studies, and was explained to the patients at the pre-anaesthetic visit as well as before giving propofol injection.

. An anaesthesiologist blinded to the study protocol evaluated pain during injection of propofol using a verbal rating scale;

$.2 \mathrm{cc}$ of propofol out of the calculated full dose of was injected and pain measured at $1 \mathrm{~min}$.

.The remaining full dose was injected after that. Adverse effects if any was noted at the same time.

$0=$ none (negative response to questioning),

$1=$ mild pain (pain reported only in response to questioning without any behavioural signs

$2=$ moderate pain (pain reported in response to questioning and accompanied by a behavioural sign or pain reported spontaneously without questioning

$3=$ severe pain (strong vocal response or response accompanied by facial grimacing, arm withdrawal)

The patients as well as the anaesthesiologist were unaware of the nature of the test drug.

1. Age

\section{OBSERVATION \& RESULTS}

Table 2: Demographical data between the two groups for age (yrs.)

\begin{tabular}{|l|l|l|}
\hline Age & Granisetron $(\mathrm{n}=41)$ & Normal saline $(\mathrm{n}=41)$ \\
\hline Mean \pm SD & $38.43 \pm 13.16$ & $42.46 \pm 13.49$ \\
\hline
\end{tabular}

$\mathrm{p}=0.1756$, using unpaired t-test indicating that the age of the patients in the NS group is significantly greater as compared to granisetron group. 
Pre-Treatment with Intravenous Granisetron to Alleviate Pain on Propofol Injection: A Double Blind...

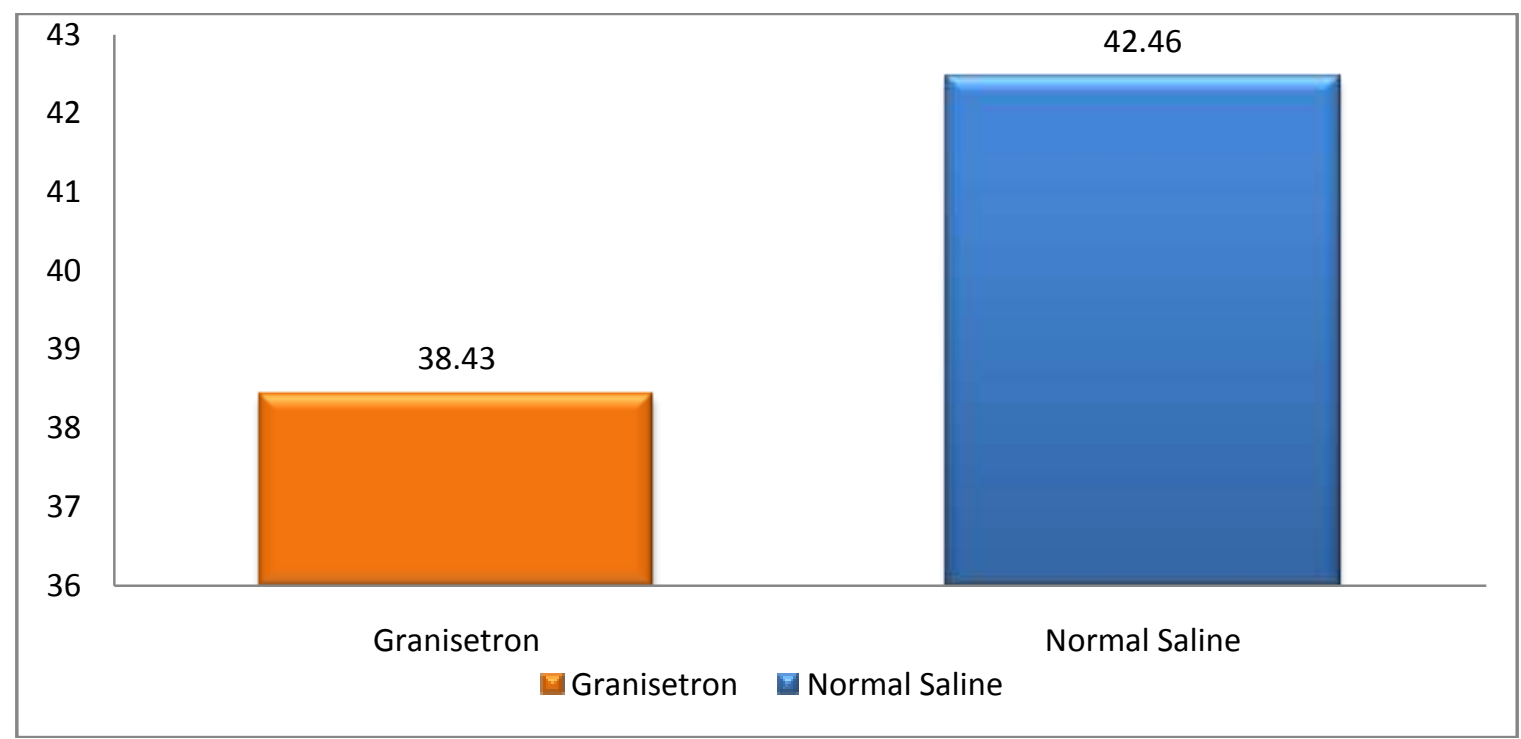

Figure 8: Mean age distribution

2.)

Gender

Table 3: Demographical data between the two groups for sex

\begin{tabular}{|l|l|l|}
\hline Gender & Granisetron & Normal saline \\
\hline Male & $16(39 \%)$ & $25(61 \%)$ \\
\hline Female & $25(61 \%)$ & $16(39 \%)$ \\
\hline Total & 41 & 41 \\
\hline p & & (n) \\
\hline
\end{tabular}

$\mathrm{p}=0.0772$, using Fisher's exact test indicating the proportion of males in NS group is significantly greater as compared to that in granisetron group.

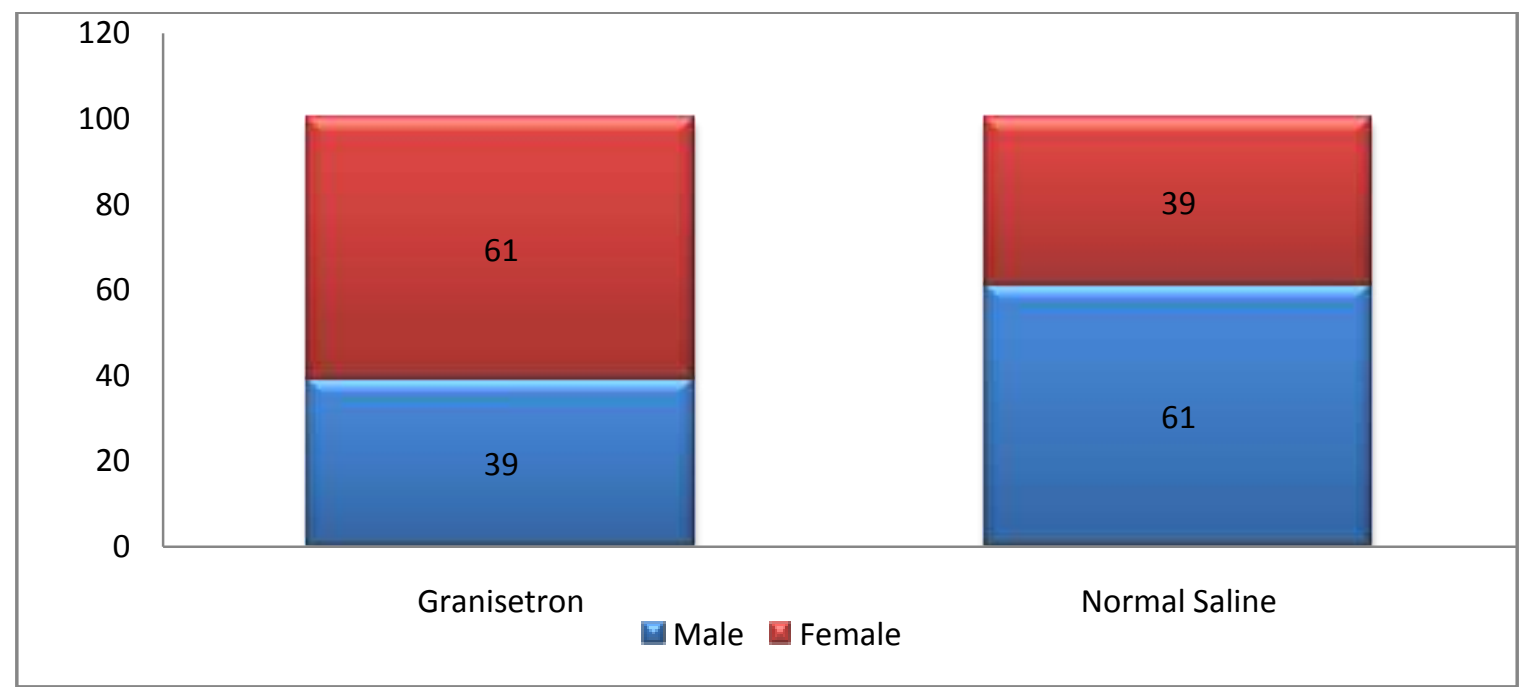

Figure 9: Sex distribution (\%)

\section{3.) Weight}

Table 4: Distribution of weight

\begin{tabular}{|l|l|l|}
\hline Weight & Granisetron $(\mathrm{n}=41)$ & Normal saline $(\mathrm{n}=41)$ \\
\hline Mean \pm SD & $61.80 \pm 7.76$ & $67.12 \pm 10.03$ \\
\hline
\end{tabular}

$\mathrm{p}=0.0978$, using unpaired t-test indicating that the weight of the patients in the NS group is significantly greater as compared to granisetron group. 
Pre-Treatment with Intravenous Granisetron to Alleviate Pain on Propofol Injection: A Double Blind...

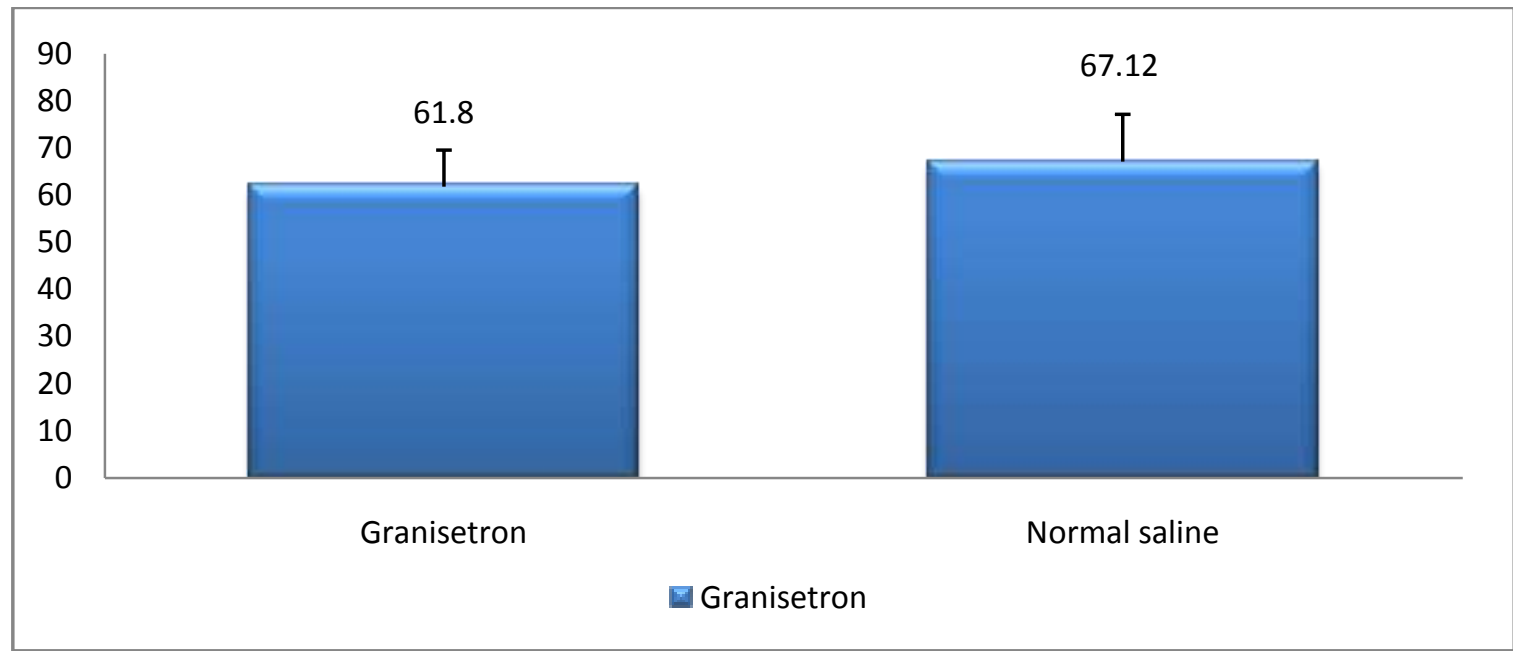

Figure 10: Mean weight

4.) ASA score

Table 5: Comparison of ASA score between the two groups

\begin{tabular}{|l|l|l|}
\hline ASA score & Granisetron & Normal saline \\
\hline I & $20(49 \%)$ & $27(66 \%)$ \\
\hline II & $21(51 \%)$ & $14(34 \%)$ \\
\hline Total & 41 & 41 \\
\hline $\begin{array}{l}p=0.1804, \text { using chi-square test indicating no significant difference in the proportion of patients belonging to } \\
\text { different ASA class in the two groups. }\end{array}$
\end{tabular}

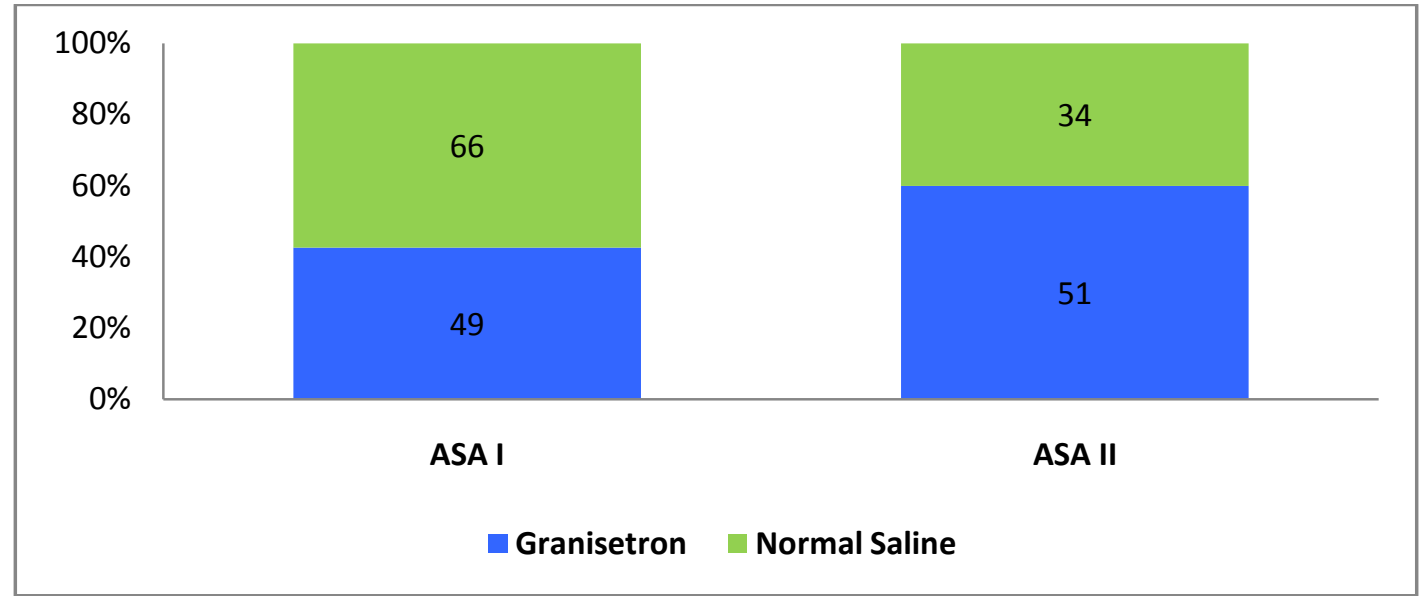

Figure 11 ASA Score

\section{5.) Heart rate}

Table 6: Comparison of heart rates between the two groups

\begin{tabular}{|c|c|c|c|}
\hline & \multicolumn{2}{|l|}{ Heart rate $($ Mean $\pm \mathrm{SD})$} & \\
\hline Event & Granisetron $(n=41)$ & Normal saline $(n=41)$ & $\mathrm{p}$ value \\
\hline Pre-injection & $75.05 \pm 10.48$ & $77.29 \pm 11.06$ & $\mathrm{p}=0.3487$ \\
\hline 1 min post-injection & $77.95 \pm 10.65^{*}$ & $83.44 \pm 11.22 * *$ & $\mathrm{p}=0.0258$ \\
\hline 3 min post-injection & $79.22 \pm 11.64 * *$ & $88.41 \pm 10.33{ }^{* *},{ }^{\#}$ & $\mathrm{p}=0.0003$ \\
\hline & $\begin{array}{l}\mathrm{p}=0.0004 \\
* \mathrm{p}<0.05, * * \mathrm{p}<0.001 \text { versus } \\
\text { pre-injection values }\end{array}$ & $\begin{array}{l}\mathrm{p}<0.0001 \\
* * \mathrm{p}<0.001 \text { versus pre- } \\
\text { injection values } \\
\# \mathrm{p}<0.001 \text { versus post- } \\
\text { injection values at } 1 \mathrm{~min} .\end{array}$ & \\
\hline
\end{tabular}


Pre-Treatment with Intravenous Granisetron to Alleviate Pain on Propofol Injection: A Double Blind...

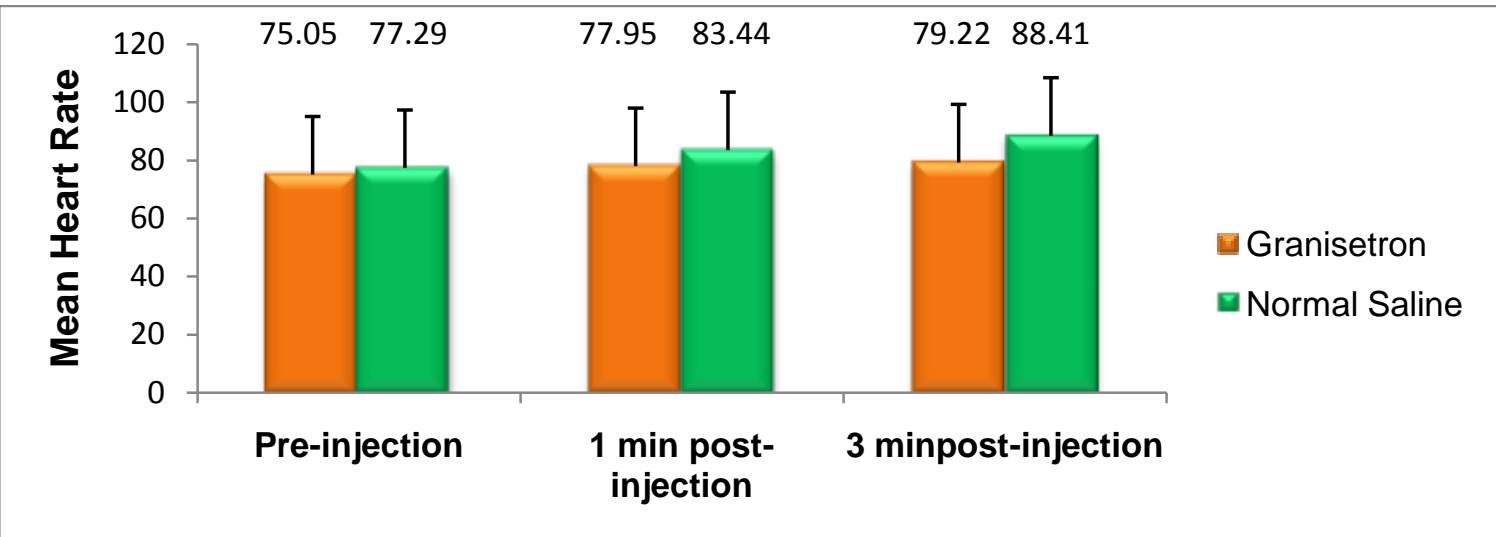

Figure12: Heart rate

4.) $\quad \mathrm{SpO2}$

Table 7: Comparison of $\mathrm{SpO} 2$ between the two groups

\begin{tabular}{|l|l|l|l|}
\hline SpO2 (Mean \pm SD) & $\begin{array}{l}\text { Granisetron } \\
(\mathrm{n}=41)\end{array}$ & $\begin{array}{l}\text { Normal saline } \\
(\mathrm{n}=41)\end{array}$ & p-value using unpaired t-test \\
\hline Pre-injection & $99.24 \pm 0.62$ & $98.90 \pm 0.89$ & $\begin{array}{l}\mathrm{p}=0.0574, \text { indicating no significant } \\
\text { difference in SpO2 between the groups }\end{array}$ \\
\hline 1 min post-injection & $99.10 \pm 0.73$ & $98.85 \pm 0.94$ & $\begin{array}{l}\mathrm{p}=0.1935, \text { indicating no significant } \\
\text { difference in SpO2 between the groups }\end{array}$ \\
\hline 3 min post-injection & $99.00 \pm 0.74$ & $99.10 \pm 0.80$ & $\begin{array}{l}\mathrm{p}=0.5685 \text { indicating no significant } \\
\text { difference in SpO2 between the groups }\end{array}$ \\
\hline $\begin{array}{l}\text { p-value using repeated } \\
\text { measures ANOVA } \\
\text { (RMANOVA) }\end{array}$ & $\begin{array}{l}\mathrm{p}=0.1280, \\
\text { indicating no } \\
\text { significant no } \\
\text { difference in } \\
\text { SpO2 at different } \\
\text { time points }\end{array}$ & $\begin{array}{l}\mathrm{p}=0.3048, \\
\text { indicating no } \\
\text { significant in } \\
\text { difference in } \\
\text { SpO2 at different } \\
\text { time points }\end{array}$ & \\
\hline
\end{tabular}

\begin{tabular}{|c|c|c|c|c|c|c|}
\hline 105 & 99.24 & 98.9 & 99.1 & 98.85 & 99 & 99.1 \\
\hline 100 & $T$ & $T$ & $T$ & $T$ & $T$ & $T$ \\
\hline 95 & & & & & & \\
\hline 90 & & & & & & \\
\hline 85 & & & & & & \\
\hline & \multirow{2}{*}{\multicolumn{2}{|c|}{ Pre-injection }} & \multicolumn{2}{|c|}{1 min post-injection } & \multirow{2}{*}{\multicolumn{2}{|c|}{$3 \mathrm{~min}$ post-injection }} \\
\hline & & & tron & Jormal Sal & & \\
\hline
\end{tabular}

Figure 13: Saturation of peripheral oxygen

5.) Systolic blood pressure

Table 8: Comparison of systolic blood pressure

\begin{tabular}{|l|l|l|l|}
\hline $\begin{array}{l}\text { Systolic blood pressure } \\
(\text { Mean } \pm \text { SD) }\end{array}$ & $\begin{array}{l}\text { Granisetron } \\
(\mathrm{n}=41) \mathrm{s}\end{array}$ & $\begin{array}{l}\text { Normal saline } \\
(\mathrm{n}=41)\end{array}$ & $\mathrm{p}$-value using unpaired t-test \\
\hline Pre-injection & $126.56 \pm 9.83$ & $136.46 \pm 10.32$ & $\begin{array}{l}\mathrm{p}<0.0001 \text { indicating that the SBP was } \\
\text { significantly higher in the NS group as } \\
\text { compared to the granisetron group. }\end{array}$ \\
\hline
\end{tabular}

Since the baseline SBP values are significantly different in both study groups, the change in SBP was calculated. 
Pre-Treatment with Intravenous Granisetron to Alleviate Pain on Propofol Injection: A Double Blind...

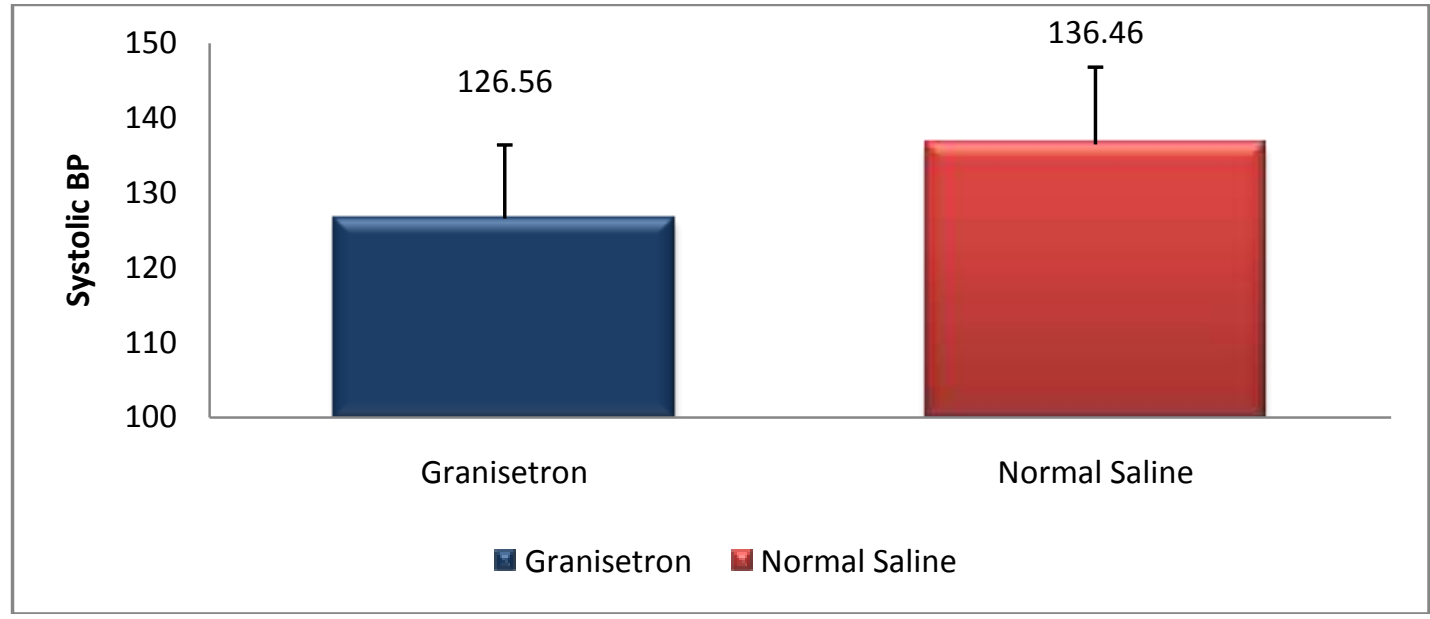

Figure 14: Systolic blood pressure

Table 9: Comparison of change in systolic blood pressure between granisetron and normal saline

\begin{tabular}{|c|c|c|c|}
\hline $\begin{array}{l}\text { Systolic blood pressure } \\
\text { (Mean } \pm \text { SD) }\end{array}$ & Granisetron $(n=41)$ & Normal saline $(n=41)$ & $\begin{array}{l}\text { p-value using unpaired t- } \\
\text { test }\end{array}$ \\
\hline 1 min post-injection & $0.21 \pm 7.62$ & $8.31 \pm 5.48$ & $\begin{array}{l}\mathrm{p}<0.0001 \text { indicating that } \\
\text { the change in SBP was } \\
\text { significantly higher in the } \\
\text { NS group as compared to } \\
\text { the granisetron group. }\end{array}$ \\
\hline 3 min post-injection & $0.65 \pm 7.61$ & $13.21 \pm 6.85$ & $\begin{array}{l}\mathrm{p}<0.0001 \text { indicating that } \\
\text { the change in SBP was } \\
\text { significantly higher in the } \\
\text { NS group as compared to } \\
\text { the granisteron group. }\end{array}$ \\
\hline $\begin{array}{l}\text { p-value using paired } t \\
\text { test }\end{array}$ & $\begin{array}{l}\mathrm{p}=0.5521 \text { indicating no } \\
\text { significant difference in } \\
\text { SBP at different time } \\
\text { points }\end{array}$ & $\begin{array}{l}\mathrm{p}<0.0001 \text { indicating } \\
\text { significant difference in } \\
\text { SBP at different time } \\
\text { points }\end{array}$ & \\
\hline
\end{tabular}

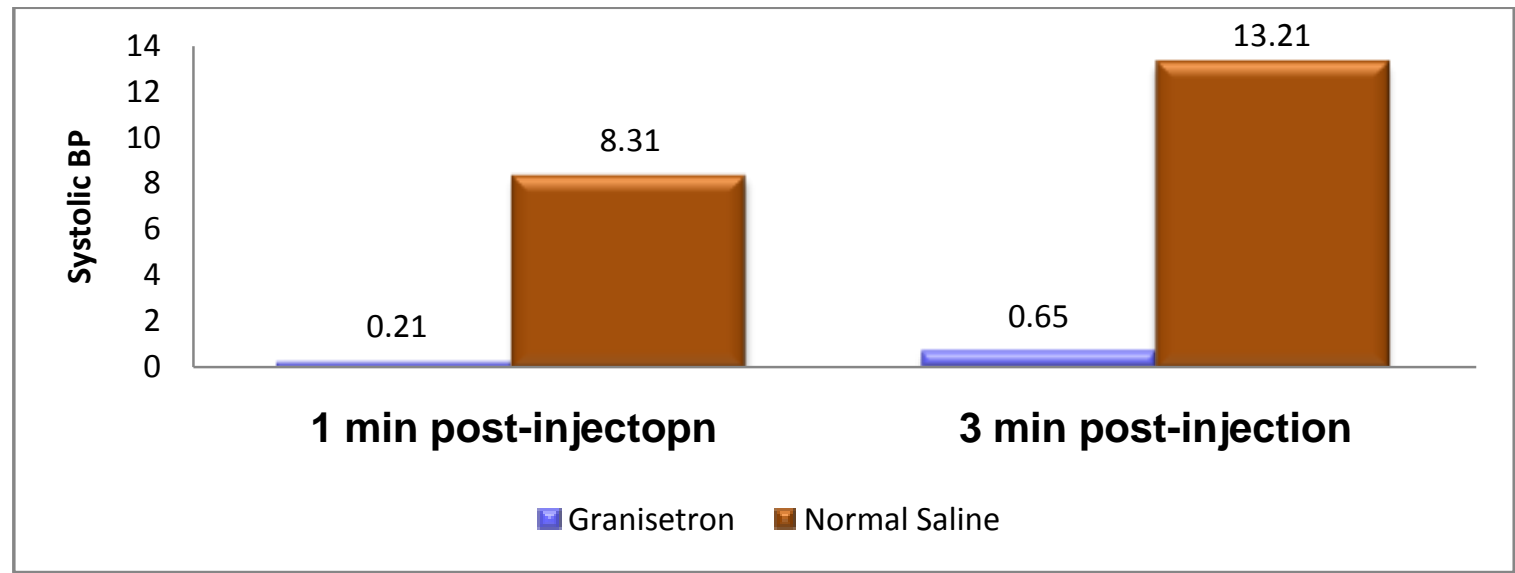

Figure 15: Change in systolic blood pressure

8. Diastolic blood pressure

Table 10 : Comparison of diastolic blood pressure between granisetron and normal saline

\begin{tabular}{|l|l|l|l|}
\hline $\begin{array}{l}\text { Diastolic blood pressure } \\
(\text { Mean } \pm \text { SD) }\end{array}$ & $\begin{array}{l}\text { Granisetron } \\
(\mathrm{n}=41)\end{array}$ & $\begin{array}{l}\text { Normal saline } \\
(\mathrm{n}=41)\end{array}$ & p-value using unpaired t-test \\
\hline Pre-injection & $80.78 \pm 6.60$ & $85.90 \pm 7.20$ & $\begin{array}{l}\mathrm{p}=0.0012 \text {, indicating that the DBP } \\
\text { was significantly higher in the NS } \\
\text { group as compared to the } \\
\text { granisterongroup. }\end{array}$ \\
\hline
\end{tabular}


Pre-Treatment with Intravenous Granisetron to Alleviate Pain on Propofol Injection: A Double Blind...

The observation indicates that the DBP was significantly higher in the NS group (85.90 \pm 7.20$)$ as compared to the granisetron group $(80.78 \pm 6.60)$.

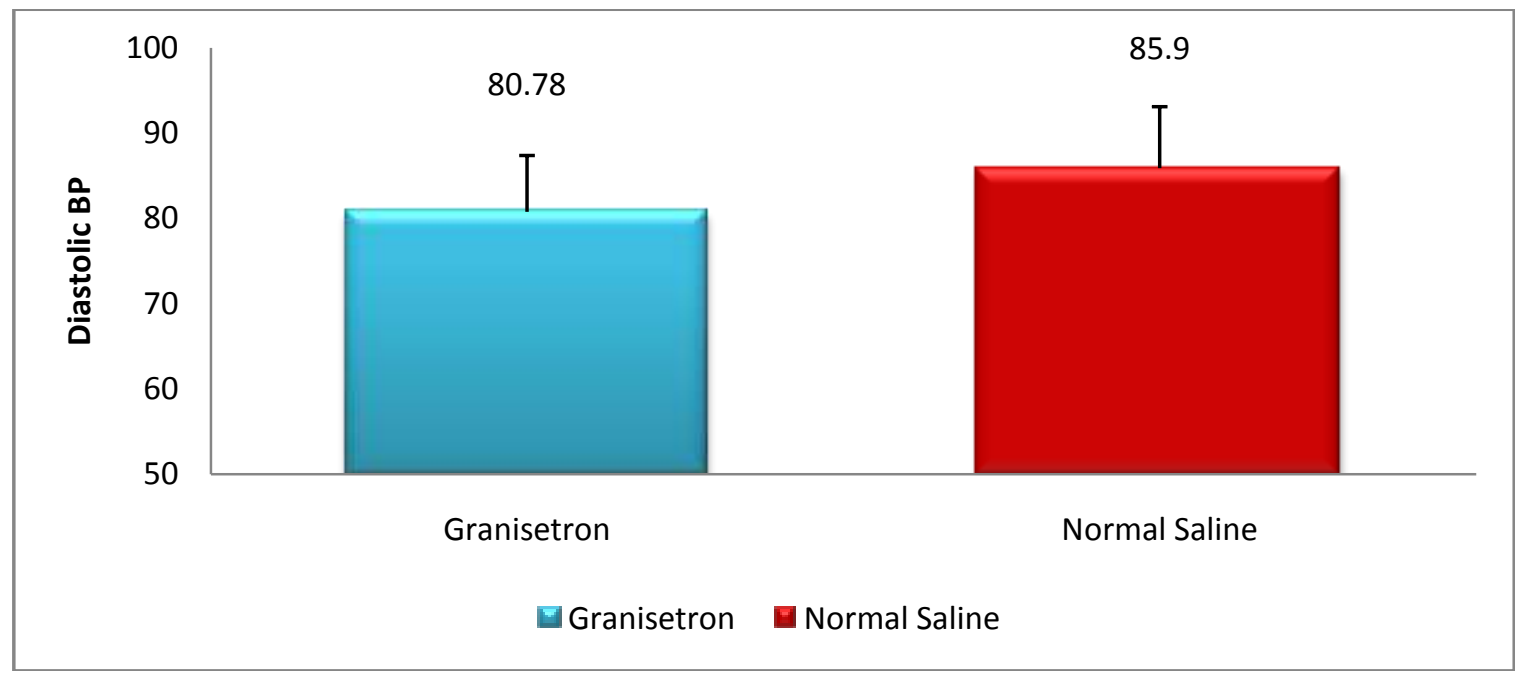

Figure 16: Diastolic blood pressure

Since the baseline DBP values are significantly different in both study groups, the change in DBP was calculated.

Table 11 : Comparison of change in diastolic blood pressure between granisetron and normal saline

\begin{tabular}{|l|l|l|l|}
\hline $\begin{array}{l}\text { Diastolic blood pressure } \\
(\text { Mean } \pm \text { SD) }\end{array}$ & $\begin{array}{l}\text { Granisetron } \\
(\mathrm{n}=41)\end{array}$ & $\begin{array}{l}\text { Normal saline } \\
(\mathrm{n}=41)\end{array}$ & $\mathrm{p}$-value using unpaired t-test \\
\hline 1 min post-injection & $0.21 \pm 6.02$ & $6.09 \pm 4.64$ & $\begin{array}{l}\mathrm{p}=<0.0001 \text {, indicating that the change } \\
\text { in DBP was significantly higher in } \\
\text { the NS group as compared to the } \\
\text { granisterongroup. }\end{array}$ \\
\hline 3 min post-injection & $0.29 \pm 6.95$ & $9.63 \pm 6.11$ & $\begin{array}{l}\mathrm{p}=<0.0001 \text {, indicating that the change } \\
\text { in DBP was significantly higher in } \\
\text { the NS group as compared to the } \\
\text { granisteron group. }\end{array}$ \\
\hline $\begin{array}{l}\text { p-value using paired t } \\
\text { test }\end{array}$ & $\begin{array}{l}0.9462 \text { indicating } \\
\text { no significant } \\
\text { difference in DBP } \\
\text { at different time } \\
\text { points }\end{array}$ & $\begin{array}{l}<0.0001 \\
\text { indicating } \\
\text { significant } \\
\text { difference in DBP } \\
\text { at different time } \\
\text { points }\end{array}$ & \\
\hline
\end{tabular}

The change in DBP was statistically significant higher in Normal Saline groups compared to granisetron group, at different time points up to 3 minutes.

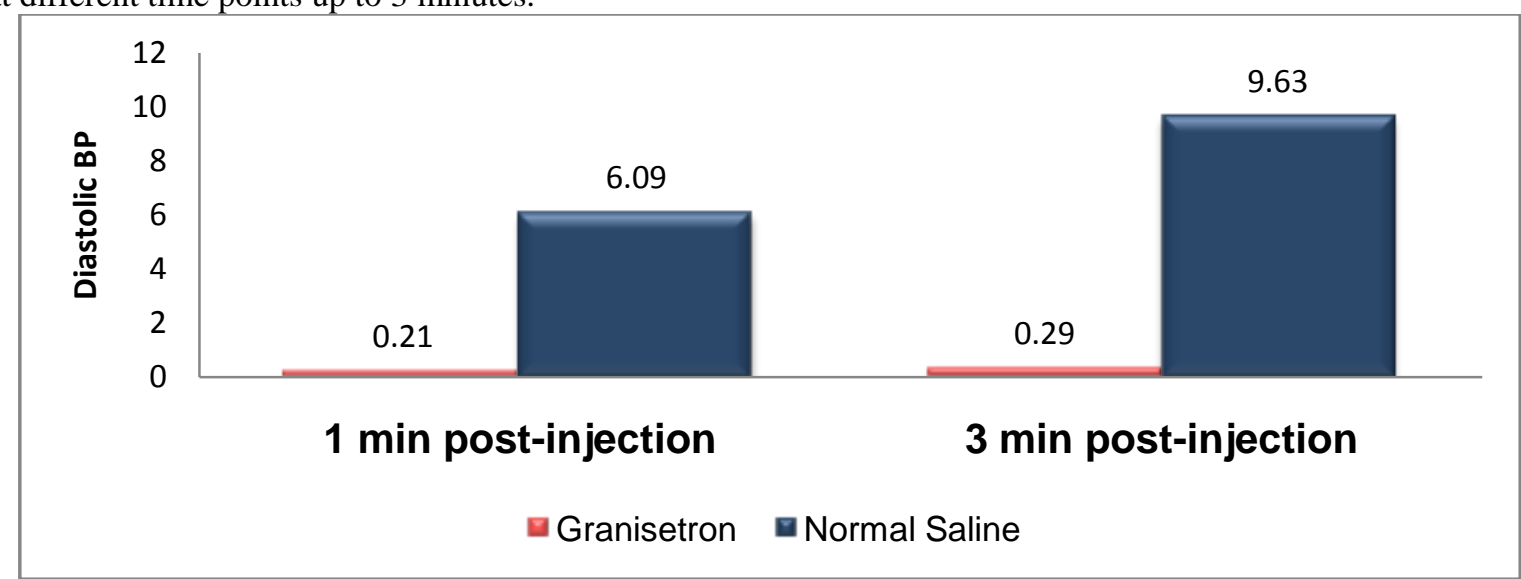

Figure 17: Change in diastolic blood pressure 
Pre-Treatment with Intravenous Granisetron to Alleviate Pain on Propofol Injection: A Double Blind...

6.) Pain on VRS during injection of propofol

Table 12: Comparison of Pain on VRS during injection of propofol between granisetron and normal saline

\begin{tabular}{|l|l|l|}
\hline Pain on VRS & Granisetron & Normal saline \\
\hline No. of patients & 41 & 41 \\
\hline Mean & 0.34 & 1.51 \\
\hline SD & 0.79 & 1.32 \\
\hline Median (Range) & 0 (0 to 3) & 2 (0 to 3) \\
\hline $\begin{array}{l}\text { p=0.0001, using Mann-Whitney test indicating that the pain score was significantly higher in the NS group as } \\
\text { compared to the granisetron group. }\end{array}$ \\
\hline
\end{tabular}

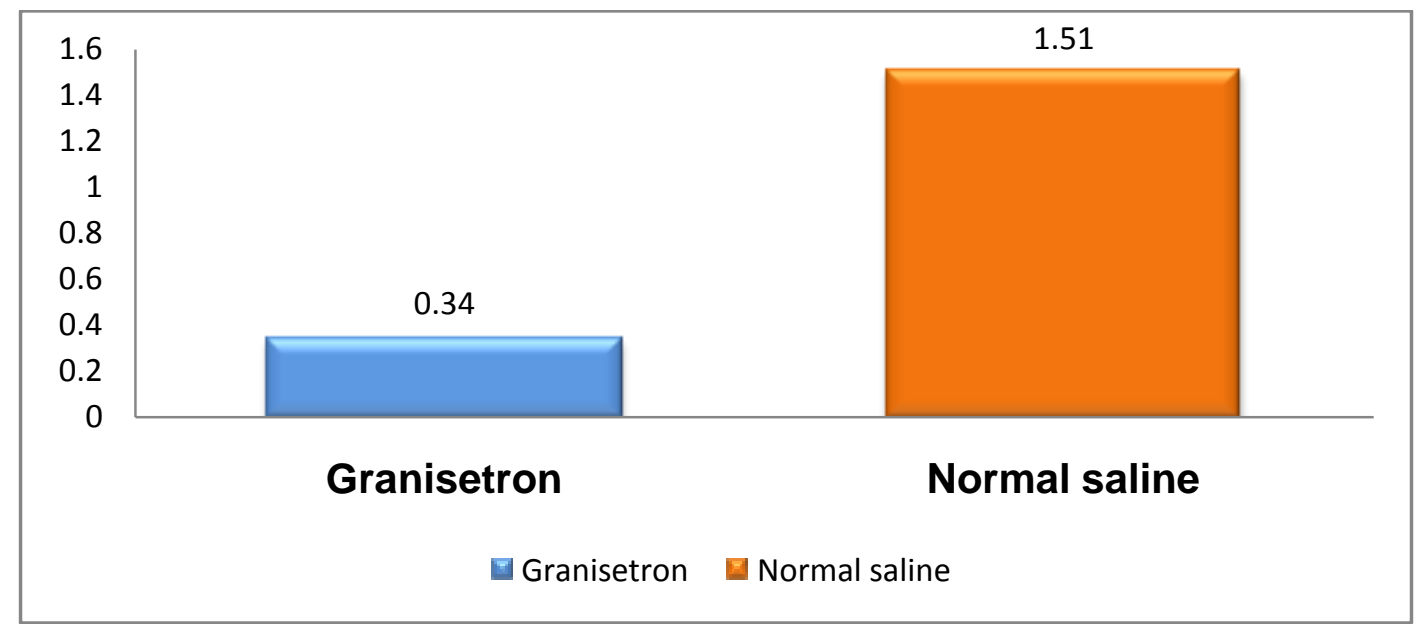

Figure 18: Pain on Verbal Rating Score

\section{DISCUSSION}

Propofol causes pain on intravenous injection and is reported in 60 percent of patients. Despite its discovery almost thirty years back and numerous randomized control trials, propofol pain is still a dilemma as it is unpredictable and very few risk factors are identifiable. The use of lidocaine to prevent propofol injection pain is the most extensively studied technique and is the most common method used in clinical practice.

Various studies have shown that 5-HT3 antagonists like ondensetron decreases the propofol induced pain by several mechanisms like a 5-HT3 receptor antagonist, Na channel blocker and $\mu$-opioid agonist(Ambesh et al., 1999) ${ }^{1}$. However, there were no studies in which efficacy of granisetron for reduction of propofol induced pain is evaluated. As 5-HT3 receptor antagonists act as $\mu$-opioid agonists that block sodium channels, it can therefore be hypothesized that granisetron may be effective in reducing the occurrence of propofol-induced pain.

This study was a prospective, randomized, double blind, active controlled study comprising 82 cases. Cases were divided into two groups of 41 patients; group A - received granisetron pre-treatment $2 \mathrm{mg}$ in a total volume of $2 \mathrm{~mL}$ whereas group B - received $2 \mathrm{~mL} 0.9 \%$ saline pre-treatment as a placebo. This study was conducted in our institute under the Department of Anaesthesia. Heart rate, blood pressure (both systolic and diastolic) and peripheral $\mathrm{O}_{2}$ saturation were the parameters recorded before injecting propofol and at 1 and 3 min after. Demographic parameters such as age, gender, weight and ASA score were also taken into account.

The ratio of men to women was 1:1.5. Age ranged from 18 to $50 \mathrm{yr}$ (Mean age: $38.43 \pm 13.16$ ), and the mean body weight was found to be $61.80 \pm 7.76$. However there was statistically significant difference between the two groups with regard to age and weight. (Age; $\mathrm{p}=0.1756$, weight; $\mathrm{p}=0.0978$ ).

Female predominance was noted in the granisetron group (61\%) compared to the normal saline group (39\%). There was no statistical significance observed between the two groups for ASA score $(\mathrm{p}=0.1804)$. The results were similar to the studies performed by Ahmed et al.

Baseline heart rate was comparable in both the groups at pre injection and $1 \mathrm{~min}$ post injection time points. However, at $3 \mathrm{~min}$, heart rate was found to be significantly lower in granisetron group (79.22 \pm 11.64$)$ compared to normal saline group $(88.41 \pm 10.33)$. This was in accordance with the study by Ahmed et al in which there was transient rise in heart rate in patients suffering from pain of verbal rating scale (VRS) score 2-3 in both the groups. (Ahmed A et al., 2012) ${ }^{42}$ There was no statistical significance difference between observations of SpO2 up to 3 minutes of observation period.

For both systolic and diastolic blood pressure, baseline SBP (prior to injection), baseline DBP (Prior to injection) and change in systolic/ diastolic BP initially prior to injection of propofol was significantly higher in control group compared to the granisetron group $(\mathrm{p}<0.0001)$. The results were consistent in the granisetron 
group. However Ahmed et al observed no changes in BP pre and post propofol injection. (Ahmed A et al., 2012) ${ }^{42}$

In this study, the mean VRS of pain on IV cannulation was $0.34 \pm 0.79$ in Granisetron group and $1.51 \pm$ 1.32 in Normal Saline group with, showing statistically significant difference between the two groups in regarding to intensity of pain on IV cannulation. $(\mathrm{p}=0.0001)$ The patients in the granisetron group gave negative response to questioning whereas patients in the saline group observed moderate pain. Ahmed et al reported overall incidence of pain in the saline group was $24(60 \%)$, compared with $6(15 \%)$ in the granisetron group $(\mathrm{p}<0.05)$. Fewer patients in the granisetron group experienced severe pain $(2.5 \%$ vs. $37.5 \% ; P<0.05)$. (Ahmed A et al., 2012 $)^{42}$ In a study by Ambesh et al. on effect of ondensetron in injection of propofol, the overall incidence of pain in the saline group was 55\%, compared with $25 \%$ in the ondensetron group ( $\mathrm{p}=0.05)$.[Ambesh SP et al., $1999]^{1}$ Singh DK et al., reported that granisetron reduced the incidence of propofol injection pain to $24 \%$ at 5 seconds, $24 \%$ at 10 seconds, $40 \%$ at 15 seconds and $40 \%$ at 20 seconds in comparison to the control group, whereas placebo had an incidence of $80 \%$ at 5 seconds, $84 \%$ at 10 seconds, $88 \%$ at 15 seconds and $88 \%$ at 20 seconds and showed statistical significance. (Singh DK et al., 2011) ${ }^{44}$ Dubey et al., also reported that the granisetron significantly reduced the incidence and severity of propofol injection pain more than placebo ( $\mathrm{p}$ $<0.001$ ). (Dubey PK et al 2003) ${ }^{45}$ The efficacy of granisetron in alleviating the pain on injection of propofol was no different from lidocaine. Ma $\mathrm{Y}$ et al., Alipour $\mathrm{M}$ et al., have also reported that granisetron decreases the propofol-induced pain on injection. (Ma YS et al., 2009) ${ }^{47}$, (Alipour M et al., 2014) ${ }^{48}$. Our study was in accordance with the reported studies.

Granisetron being an anti-emetic it can also help in reduction of post-operative nausea and vomiting. Thus use of granisetron as pre-treatment drug provides an added advantage. Many drugs have been studied to reduce the pain caused by injection of propofol before the surgery. So far lidocaine is the best strategy proven. Granisetron being the serotonin 5 HT-3 receptor antagonist can be used as a safe and efficacious alternative to lidocaine. Moreover, being an anti-emetic it can also decrease the post -operative complications.

In conclusion,

\section{Conclusion}

1.) Granisetron pre-treatment decrease the heart rate, systolic and diastolic blood pressure and pain on injection of propofol.

2.) In comparison with normal saline granisetron was better to reduce the pain on propofol injection

3.) The results of this study were comparable with other studies, which also show similar results.

4.)It provides a simple and safe method of reducing the incidence of pain on injection of propofol with the added advantage of avoiding the administration of other drugs that may be undesirable in certain circumstances

\section{REFERENCES}

[1]. Ambesh SP, Dubey PK, Sinha PK. Ondensetron pre-treatment to alleviate pain on propofol injection: a randomized, controlled, double-blinded study. Anaesthesia \& Analgesia, 1999;89(1):197-199.

[2]. Macario A, Weinger M, Truong P, Lee M. Which clinical anesthesia outcomes are both common and important to avoid? The perspective of a panel of expert anesthesiologists. Anaesth Analg. 1999; 88: 1085-91.

[3]. Bleeker C, Vree T, Lagerwerf A, Willems-van Bree E. Recovery and long-term renal excretion of propofol, its glucuronide, and two di-isopropylquinol glucuronides after propofol infusion during surgery. Br J Anaesth. 2008 Aug;101(2):207-12.

[4]. Takizawa D, Hiraoka H, Goto F, Yamamoto K, Horiuchi R. Human kidneys play an important role in the elimination of propofol.Anesthesiology. $2005 \mathrm{Feb}$;102(2):327-

[5]. Kuipers JA, Boer F, Olieman W, Burm AG, Bovill JG. First-pass lung uptake and pulmonary clearance of propofol: assessment with a recirculatory indocyanine green pharmacokinetic model. Anesthesiology. 1999 Dec;91(6):1780-7.

[6]. Hughes MA, Glass PS, Jacobs JR. Context-sensitive half-time in multicompartment pharmacokinetic models for intravenous anesthetic drugs. Anesthesiology. 1992 Mar;76(3):334-41.

[7]. Kazama T, Ikeda K, Morita K, Kikura M, Doi M, Ikeda T, Kurita T, Nakajima Y. Comparison of the effect-site k(eO)s of propofol for blood pressure and EEG bispectral index in elderly and younger patients. Anesthesiology. 1999 Jun;90(6):1517-27.

[8]. Shafer A, Doze VA, Shafer SL, White PF. Pharmacokinetics and pharmacodynamics of propofol infusions during general anesthesia. Anesthesiology. 1988 Sep;69(3):348-56.

[9]. Kazama T, Kurita T, Morita K, Nakata J, Sato S. Influence of hemorrhage on propofol pseudo-steady state concentration.Anesthesiology. 2002 Nov;97(5):1156-61.

[10]. Allegaert K, de Hoon J, Verbesselt R, Naulaers G, Murat I. Maturational pharmacokinetics of single intravenous bolus of propofol.Paediatr Anaesth. 2007 Nov;17(11):1028-34.

[11]. Kirkpatrick T, Cockshott ID, Douglas EJ, Nimmo WS. Pharmacokinetics of propofol (diprivan) in elderly patients. Br J Anaesth. $1988 \mathrm{Feb} ; 60(2): 146-50$.

[12]. Vuyk J, Lichtenbelt BJ, Olofsen E, van Kleef JW, Dahan A. Mixed-effects modeling of the influence of midazolam on propofol pharmacokinetics. Anesth Analg. 2009 May; 108(5):1522-30.

[13]. Alford DP, Compton P, Samet JH. Acute Pain Management for Patients Receiving Maintenance Methadone or Buprenorphine Therapy. Annals of internal medicine. 2006;144(2):127-134.

[14]. Krasowski MD, Koltchine VV, Rick CE, Ye Q, Finn SE, Harrison NL. Propofol and other intravenous anesthetics have sites of action on the gamma-aminobutyric acid type A receptor distinct from that for isoflurane. Mol Pharmacol. 1998 Mar;53(3):530-8. 
[15]. Xie G, Deschamps A, Backman SB, Fiset P, Chartrand D, Dagher A, Plourde G. Critical involvement of the thalamus and precuneus during restoration of consciousness with physostigmine in humans during propofol anaesthesia: a positron emission tomography study. Br J Anaesth. 2011 Apr;106(4):548-57.

[16]. Dong XP, Xu TL. The actions of propofol on gamma-aminobutyric acid-A and glycine receptors in acutely dissociated spinal dorsal horn neurons of the rat. Anesth analg. 2002 Oct;95(4):907-14

[17]. Cechetto DF, Diab T, Gibson CJ, Gelb AW. The effects of propofol in the area postrema of rats. Anesth Analg. 2001 Apr;92(4):934-42.

[18]. Glass PS, Bloom M, Kearse L, Rosow C, Sebel P, Manberg P. Bispectral analysis measures sedation and memory effects of propofol, midazolam, isoflurane, and alfentanil in healthy volunteers. Anesthesiology. 1997 Apr;86(4):836-47.

[19]. Wilson C, Canning P, Caravati EM. The abuse potential of propofol. Clin Toxicol (Phila). 2010 Mar;48(3):165-70.

[20]. Noterman J, Berre J, Vandesteene A, Brotchi J. [Monitoring of intracranial pressure during the postoperative period of aneurysms]. Neurochirurgie. 1988;34(3):161-3.

[21]. Steiner LA, Johnston AJ, Chatfield DA, Czosnyka M, Coleman MR, Coles JP, Gupta AK, Pickard JD, Menon DK. The effects of large-dose propofol on cerebrovascular pressure autoregulation in head-injured patients. Anesth Analg. 2003Aug;97(2):572-6.

[22]. 23.) Kazama T, Ikeda K, Morita K, Sanjo Y. Awakening propofol concentration with and without blood-effect site equilibration after short-term and long-term administration of propofol and fentanyl anesthesia. Anesthesiology. 1998 Apr;88(4):928-34.

[23]. Goodman NW, Black AM, Carter JA. Some ventilatory effects of propofol as sole anaesthetic agent. Br J Anaesth. 1987 Dec;59(12):1497-503.

[24]. Xia Z, Huang Z, Ansley DM. Large-dose propofol during cardiopulmonary bypass decreases biochemical markers of myocardial injury in coronary surgery patients: a comparison with isoflurane. Anesth Analg. 2006 Sep;103(3):527-32.

[25]. Jalota L, Kalira V, George E, Shi YY, Hornuss C, Radke O, Pace NL, Apfel CC; Perioperative Clinical Research Core. Prevention of pain on injection of propofol: systematic review and meta-analysis. BMJ. 2011 Mar 15;342

[26]. Russel et al. Incidence of propofol-related infusion syndrome in critically ill adults: a prospective, multicenter study. Crit Care. 2009;13(5): R169.

[27]. Picard P, Tramer MR. Prevention of pain on injection with propofol: a quantitative systematic review. AnaesthAnalg 2000; 90:963-9.

[28]. Walker BJ, Neal JM, Mulroy MF, Humsi JA, Bittner RC, McDonald SB. Lidocaine pretreatment with tourniquet versus lidocainepropofol admixture for attenuating propofol injection pain: a randomized controlled trial. RegAnesth Pain Med 2011; 36: 41-5.

[29]. McCrirrick A, Hunter S. Pain on injection of propofol: The effect of injectate temperature. Anaesthesia. 1990;45:443-4.

[30]. Stokes DN, Robson N, Hutton P. Effect of diluting propofol on the incidence of pain on injection and venous sequelae. $\mathrm{Br} \mathbf{J}$ Anaesth. 1989;62:202-3.

[31]. Valtonen M, Iisalo E, Kanto J, Rosenberg P. Propofol as an induction agent in children: Pain on injection and pharmacokinetics. ActaAnaesthesiol Scand. 1989;33:152-5.

[32]. Tariq MA, Kamran M. Incidence of pain on propofol injection and efficacy of addition of lignocaine or selecting big vein or both combined in reducing it: a randomized control trial. J Postgrad Med Inst. 2006;20:8-11.

[33]. Roche. Kytril (granisetron hydrochloride) injection prescribing information. Nutley, NJ; 2002 Aug.

[34]. Natural Medicines Comprehensive Database. http://www.naturaldatabase.com, accessed on 21/11/15.

[35]. May FE, Stewart RB, Cluff LE. Drug interactions and multiple drug administration. Clin Pharmacol Ther. 1977;22:322-328.

[36]. Karas S Jr. The potential for drug interactions. Ann Emerg Med. 1981;10:627-630.

[37]. Bloomer JC, Baldwin SJ, Smith GJ et al. Characterisation of the cytochrome P450 enzymes involved in the in vitro metabolism of granisetron. Br J Clin Pharmacol 1994;38:557-566.

[38]. Roche. Kytril (granisetron hydrochloride) tablets and oral solution prescribing information. Nutley, NJ; 2001 Jun.

[39]. Porteous R. Pain-free intravenous injections [letter]Anaesthesia.1987;42:1021.

[40]. Briggs LP, Clarke SJ, Dundee JW, Moore J, Bahar M, Wright PJ. Use of di-isopropyl phenol as main agent for short procedures. Br J Anaesth. 1981;53:1197-202.

[41]. Ahmed A, Sengupta S, Das T, Rudra A, Iqbal A. Pre-treatment with intravenous granisetron to alleviate pain on propofol injection: A double-blind, randomized, controlled trial. Indian J Anaesth. 2012;56(2):135-138.

[42]. Ye JH, Mui WC, Ren J, Hunt TE, Wu WH, Zbuzek VK. Ondansetron exhibits the properties of a local anesthetic.Anesth Analg. 1997 Nov; 85(5):1116-21.

[43]. Singh DK, Jindal P, Singh G. Comparative study of attenuation of the pain caused by propofol intravenous injection, by granisetron, magnesium sulfate and nitroglycerine. Saudi J Anaesth. 2011;5(1):50-54.

[44]. Dubey PK, Prasad SS. Pain on injection of propofol: the effect of granisetron pretreatment. Clin J Pain. 2003 Mar-Apr;19(2):121-

[45]. Goyal R, Jindal P, Khurana G. A comparison of granisetron and nitroglycerine for attenuating rocuronium pain: A double-blinde randomized, placebo controlled trial. Saudi J Anaesth. 2014;8(1):83-87.

[46]. Ma YS, Lin XM, Zhou J. Effects of granisetron/lidocaine combination on propofol injection-induced pain: a double-blind randomized clinical trial. Sichuan Da Xue Xue Bao Yi Xue Ban. 2009 May;40(3):536-8. Chinese.

[47]. Alipour M, Tabari M, Alipour M. Paracetamol, ondansetron, granisetron, magnesium sulfate and lidocaine and reduced propofol injection pain. Iran Red Crescent Med J. 2014 Mar;16(3):e16086. 